\begin{tabular}{|c|c|c|}
\hline & JSM (9) (1) & \\
\hline & JURNAL SENI MUSIK & \\
\hline & https://journal.unnes.ac.id/sju/index.php/jsm/index & \\
\hline
\end{tabular}

\title{
FORM AND STRUCTURE SELECTED SONGS FROM KIDUNG PENGHIBURAN CONSOLATION WORSHIP IN GKI INDRAMAYU
}

\author{
Alberta Dm ${ }^{\otimes 1}$ \\ Moh. Muttaqin $^{\otimes 2}$
}

Department of Drama, Dance, and Music, Language and Art Faculty, Semarang State University, Indonesia

\begin{tabular}{l}
\hline Article Info \\
\hline Received February 2020 \\
Approved March 2020 \\
Published June 2020 \\
\\
\hline Keywords: \\
Analysis, Song Form, \\
Selected Song, Kidung \\
Penghiburan
\end{tabular}

\section{Abstrak}

Analisis bentuk lagu bertujuan untuk mengupas dan mengurai lagu secara menyeluruh agar unsur-unsur yang terdapat di dalamnya dapat ditemukan. Permasalahan yang dibahas dalam penelitian ini adalah bagaimana bentuk serta struktur dari lagu-lagu yang terdapat dalam Kidung Penghiburan. Penelitian ini menggunakan metode deskriptif kualitatif. Pengumpulan data dilakukan dengan teknik observasi, dan dokumentasi. Teknik keabsahan data yang digunakan adalah triangulasi. Analisis data dilakukan dengan reduksi data, penyajian data, penarikan kesimpulan dan verifikasi. Hasil penelitian menunjukkan bahwa bentuk struktur lagu-lagu pada Kidung Penghiburan, yaitu lagu: Pintu Gebang Terbukalah, Jalan Hidup Tak Selalu, Makin Dekat Tuhan, dan Tuhan Allah Beserta Engkau terdiri dari bentuk dua bagian dengan struktur frase dan bentuk pengolahan motif yang berbeda. Lagu Pintu Gebang Terbukalah memiliki pola A (a a'), B (b y), Jalan Hidup Tak Selalu memiliki pola A (a a'), A' (a x), B (b y), Makin Dekat Tuhan memiliki pola A (a a'), B (b a'), dan Tuhan Allah Beserta Engkau memiliki pola A (a a'), B (b b').

Abstract

Analysis of music form aims to peel and unravel the song thoroughly so that the contained elements in it can be found. The problem statement in this research is analysis of form song from Kidung Penghiburan. This research uses descriptive qualitative method and using several data collection techniques, including observation and documentation studies. Data will be validated by data triangulation. Data analysis techniques in this research uses data reduction, data presentation, conclusion withdrawal and verification. The result of this research showed that the songs from Kidung Penghiburan titled Pintu Gebang Terbukalah, Jalan Hidup Tak Selalu, Makin Dekat Tuhan, and Tuhan Allah Beserta Engkau are the two-part songs with different phrases arrangement and motif tabulation. Pintu Gebang Terbukalah's form is $A\left(a a^{\prime}\right), B(b y)$, Jalan Hidup Tak Selalu's form is $A\left(a a^{\prime}\right), A^{\prime}(a x), B(b y)$, Makin Dekat Tuhan's form is $A\left(a a^{\prime}\right), B\left(b a^{\prime}\right)$, and Tuhan Allah Beserta Engkau's form is $A\left(a a^{\prime}\right), B\left(b b^{\prime}\right)$.

(C) 2020 Universitas Negeri Semarang

\footnotetext{
$\triangle$ Departement of Dance, Drama and Music Education UNNES

Gunungpati, Semarang 50229

Email : 1.albertadm01@gmail.com

2. mutagimn@gmail.com
} 


\section{INTRODUCING}

According to Sunarto, music is the content of the human heart that is shed in the form of regular sounds with melody or rhythm and has a beautiful element of harmony (Rachman, 2013:70). Not only in the psychological sense but music also plays a part in the complementary of human life in a social, cultural, and religious way. Music can have a tremendous impact. Music has a positive influence when it is positioned at a good place, and music can also have a negative influence when it is positioned at the wrong place. Therefore, music is often used by Christians to fulfill their religious needs (Wijoyo, 2014). Music cannot be separated from the lives of christians. Through music or singing, the people express readiness to appear before the Lord, asking the Lord to be present, to confess their sins, to ask forgiveness, to give thanks and to ask for the Lord's blessing. Music became the direct instrument of the congregation of worship, both as a person and as a communion (together). Congregational singing is the most basic and is considered to be the center of all music and other songs in church worship (Siahaan, 2012). Music has a function as an instrument of worship. Music became a means of unifying the congregation with the Lord especially to the congregations of the church. Church congregations conduct worship by singing hymns addressed to the Lord. Therefore music plays a significant role in affecting congregational attendance in a worship. So it can be said that music is one of the chains of liturgy whose existence cannot be separated from the whole chain of worship (Suryanto, 2014:2). Of all the hymns used for Christian worship, there are several categories of songs used for Christian worship, their use being adjusted to the liturgy of each church and the type of worship.

One type of category of congregational singing is song of praise. The song of praise is better known as hymns with verse form following the Greek literary code that follows storfe.
The message or content of the hymn developed from verse to verse without the chorus; With words that speak of God, Jesus Christ, the holy ghost, God is three in one, the truth of the Lord's word, nature and environment as well as social matters. Notations or tones usually have the same value, very few use tones that are $1 / 8$ (eighth) or 1/16 (eleven) (Siahaan, 2012). GKI Indramayu was one of the churches that used hymns in her services.

GKI Indramayu is the oldest protestant church in Indramayu and the oldest church for the GKI region of West Java. The church which houses the building on Cimanuk No. 23/ G, the inauspicious family, indramayu district. GKI Indramayu has various categories of worship that are not so different from other churches, such as regular Sunday worship carried out on Sunday, ecclesiastical holiday services performing in celebration of events of Christ throughout the year, as well as family worship such as stake communion, home worship, engagement worship, and consolation. Of the many types of worship carried out, the consolation worship is a separate worship for the purpose of giving strength and consolation to a congregation in which a family member or relative has just experienced the event of death.

It belongs to a special kind of worship that has its own meaning, a consolation worship using a special song the theme has adapted to the giving of strength and consolation. These songs are summarized in a book entitled Kidung Penghiburan. It consists of 55 songs composed of hymns from the song of the song, songs of new songs, and complements of the song with some additional themes of consolation and encouragement that attract researchers to analyze. According to Prier (1996: 1), music analysis is 'cutting' and paying attention to details while forgetting the entirety of a piece of music. The whole means looking at the beginning and the end of a song and some temporary stops in the middle, the waves up and down and its peak place. While the shape of the song according to Jamalus (1988: 35) is arrangement and relationship between the elements of the music in a song resulting in 
a meaningful composition or song. Analysis of musical forms means cutting, paying attention, and dissecting musical elements found in a song. Among the musical elements discussed in this study are the following; Song, sentence, motive, and cadences. So sample songs selected from the Kidung Penghiburan will be peeled and decomposed thoroughly.

The problems that will be examined in this study analyze the shape and structure of selected songs in Kidung Penghiburan used for worship of consolation. The previous studies discussing song form analysis are (Wijoyo, 2014) about the form and function of praise music in Sunday worship at GBI Gajahmada. Another similar study was by Saputra (2016).

\section{MATERIAL AND METHOD}

The study used qualitative descriptive methods. Bogdan and Taylor in Moleong (2009: 4) describe that qualitative methods are research procedures that produce descriptive data in the form of written or oral words from the people and actors observed. Whereas Kirk and Miller define qualitative research as certain traditions in social science that fundamentally depend on observing humans in their own region and dealing with these people in their discussions and terminology (Moleong, 2009: 4). Researchers use a qualitative type of descriptive study because they want to describe the process of selecting songs in Kidung Penghiburan for consolation worship and describe the results of the analysis of the selected song. The study is conducted at GKI Cimanuk No.23/G, Karangmalang, Indramayu Regency. The objective of this study is both worship and song director. The object taken as data in this study is a sample of selected songs along with the original notations in Kidung Penghiburan. The data-collection technique used in this study are observations, interviews, and documentations.

The validity technique of the data used is triangulation. Whereas in data analysis techniques, three activities are performed with data reduction, presentation of data, and a withdrawal of conclusions and verification.

\section{RESULT AND DISCUSSION}

The Indonesian Christian Church, or GKI, is one of the largest church synods of Indonesia and is the combined result of three churches; GKI East Java, GKI Central Java, and GKI West Java. The history of GKI West Java begins with a person named Ang Boen Swie who spreads understanding of God's word in indramayu. Activities surrounding understanding God's word then continued to grow to other families so that on December 13th, 1858 baptized 14 souls from 5 families. On December 13, 1858, it was later inaugurated as the date for the establishment of GKI Indramayu. It is a historic church and is the oldest church in the west GKI Java synod, as is the other church GKI indramayu has liturgy used to be an axis in her services.

There are many types of worship held in GKI Indramayu, one of which is the consolation worship aimed at giving strength, hope or motivation and consolation to members of the congregation/people whose family members or relatives have passed away.

Losing loved ones in death is the greatest loss of our lives. Death is our permanent symbol or farewell with our loved ones or families. Death is a sign of separation from our loved ones or relatives. So that death events result in those left behind suffering emotionally, socially, or psychologically (Pasila, 2017: 1). Hence, those left behind should be helped to endure difficult times. The community has different ways of consoling the bereaved, such as whether there is a ceremonial ritual or a religious one.

The song has always been found in a series of ecclesiastical liturgy, so song is an integral part of the church liturgy. Liturgy is the official worship of the Christian religion in which songs of praise and prayer are found. The chanting in worship can appear in one testimony, with praise to God and an expression of acceptance of the word of God. Therefore, 
singing in worship should be the bearer and interpreter of God's word, the living voice of the Gospel itself (Yusuf, 2017: 41). In addition, the music used for church worship is instrumental in sustaining an atmosphere of worship. The singing of the congregation can make an atmosphere of worship more reverent, can even help the people pray through the song, as through the song, the prayer can be expressed in a more interesting way. Music in worship may be referred to as music of praise or of liturgy songs. This liturgy song is a music composed for the observance of worship or a song created exclusively for worship as one of the functional songs in the liturgy sequence. Semua nyanyian rohani untuk keperluan pertemuan, pementasan, maupun hiburan digolongkan ke dalam nyanyian non-liturgis (Adimurti, 2005).

In case studies in GKI Indramayu, this church used special songs that have had their moments adjusted to the consolation worship. These are summarized in Kidung Penghiburan that contains 55 songs. Each of the 55 songs has a common verse characteristic of the giving of strength and consolation to a people faced with the death of his family or relatives and having no mournful melodies.

The songs of Kidung Penghiburan are unique in that they have different meanings. But ultimately, the creator of music conveys his ideas, thoughts, feelings, and message through musical productions. The message to be conveyed through a piece of music sometimes does not reach the listener, or the listener has a different understanding of what is meant by the creator.

Therefore to understand a musical work, sufficient knowledge is needed, so that the listener is able to receive the message to be conveyed by its creator (Destiana, 2016: 209).

To gain sufficient understanding, the theory of music analysis was obtained because it had elements of its own composition. In music, there are patterns such as rhythmic, melodic, and harmony as its constituent elements (Roziqin \& Sarjoko, 2018: 3). Therefore, the shape or structure of a song is an arrangement and relationship between music elements that are interrelated in the song so as to produce a meaningful song or composition (Jamalus, 1988: 35). The song form according to the number of sentences is divided into: (1) form one part song, (2) form a two-part song, (3) form a three-part song.

The songs included in Kidung Penghiburan are then drawn for analysis, which is "Pintu Gerbang Terbukalah" by Silas J. Vail (Kidung Penghiburan No.1), "Jalan Hidup Tak Selalu" by Flora Kirkland (Kidung Penghiburan No. 14), the "Makin Dekat Tuhan" by Lowell Mason (Kidung Penghiburan No.22), and "Tuhan Allah Beserta Engkau" by William G. Tomer (Kidung Penghiburan No.46).

\section{"Pintu Gerbang Terbukalah" Song Analysis}

Silas J. Vail wrote "the opened gate." (1818-1884) with a poem written by Baxter sea (1809-1874) under the original title "The Gate Ajar For Me" (translated by GKI singing team 1990). This song is a 16 measure song with the base tones of do $=\mathrm{c}$. It is included in a two-part song with pattern such as $A B=A\left(a a^{\prime}\right), B\left(b y^{\prime}\right)$. A song form with the pattern $A$ ( $a$ a ') B (b y) means the question in sentence $A$ is repeated as an answer sentence with variations (Prier 1996: 9). From the analysis of the sentence, it is known that in part a, (a) phrase antecedent is in the $1^{\text {st }}$ $4^{\text {th }}$ barline and ( $\left.\mathrm{a}^{\prime}\right)$ consequent phrase is in the $5^{\text {th }}-8^{\text {th }}$. In part $b,(b)$ antecedent phrase lies between $9^{\text {th }}-12^{\text {th }}$ barline and $13^{\text {th }}-$ $16^{\text {th }}$ is (b) consequent phrase.

The various types of motif processing can be found in Pintu Gerbang Terbukalah song, but underline that the whole motive is the development of $1^{\text {st }}$ motive in the song.

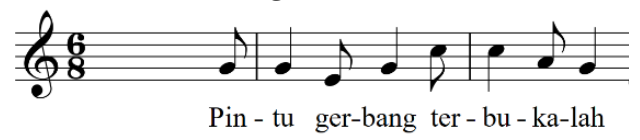

$1^{\text {st }}$ Notation: $1^{\text {st }}$ motive in A sentence on Pintu Gerbang Terbukalah song, Alberta, personal documentation. (made on July $4^{\text {th }}, 2019$ ) 
In phrase antecedent in $\mathrm{A}$ sentence, the processing of the motive found is the sequence down on $2^{\text {nd }}$ motive. A descending sequence is a repetition of motifs at a lower pitch (Prier 1996: 28). Here is a comparison between $1^{\text {st }}$ motive to $2^{\text {nd }}$ motive which $2^{\text {nd }}$ motive is a recurrence of $1^{\text {st }}$ motive but at a different level of tone.

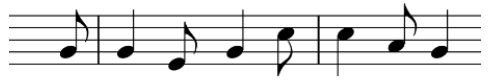

Pin - tu ger-bang ter - bu - ka-lah

the motive of A sentence become

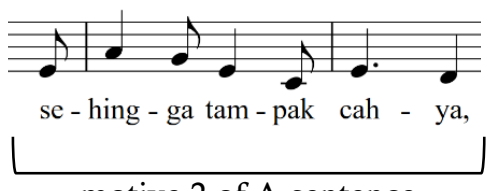

motive 2 of A sentence

$2^{\text {nd }}$ Notation: $1^{\text {st }}$ motive and $2^{\text {nd }}$ motive in A sentence on Pintu Gerbang Terbukalah song, Alberta, personal documentation. (made on July $4^{\text {th }}$, 2019)

Nonharmonic tones are also found in $2^{\text {nd }}$ motif of the nonharmonic tones of appoggiatura. Appoggiatura is dissonant with a jump (interval of three or greater intervals) and is resolved by a stepping motion, usually in the direction of motion opposite the jumping motion (Ottman, 1961: 130).

In consequent phrases in sentence $\mathrm{A}$, the processing of a range of literal repetitions is found on $3^{\text {rd }}$ motive. A harari test is a repetition that repeats at the same time (Prier, 1996: 28).

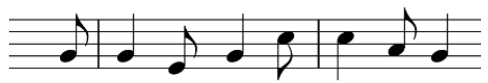

Pin - tu ger-bang ter - bu - ka-lah

$1^{\text {st }}$ motive in A sentence become

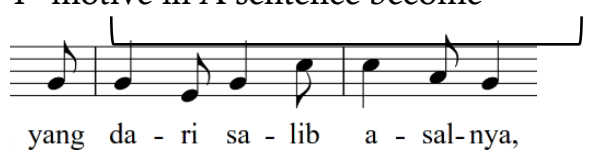

$3^{\text {rd }}$ motive of A sentence $3^{\text {rd }}$ Notation: Repetition of $3^{\text {rd }}$ motive and $1^{\text {st }}$ motive in A sentence on Pintu Gerbang Terbukalah song, Alberta, personal documentation. (made on July $4^{\text {th }}, 2019$ )

Whereas the sequence on $4^{\text {th }}$ motive, the processing of the highest type of sequence was found. An ascending sequence is a repetition of motives at a higher pitch level (Prier, 1996: 28).
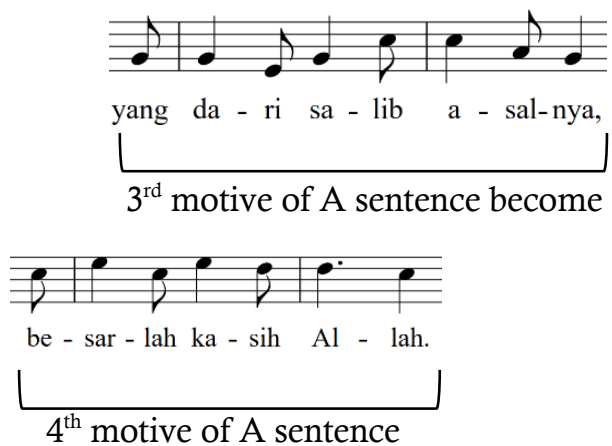

$4^{\text {th }}$ Notation: Repetition of $4^{\text {th }}$ motive and $3^{\text {rd }}$ motive in A
sentence on Pintu Gerbang Terbukalah
song, Alberta, personal documentation.
(made on July $4^{\text {th }}, 2019$ )

Nonharmonic tones were later found on $4^{\text {th }}$ motif is kinds of escaped tones. Dalam escaped tones, nada disonan mendekat dengan melangkah dan diselesaikan dengan cara melompat, biasanya dalam arah berlawanan dengan nada yang mendekatinya (Ottman 1961:30).

Further, the processing of the output of the sequence rises in the $1^{\text {st }}$ motive of phrase antecedent of $b$ sentence . If a descending sequence is a repetition of notes at a lower level, then an ascending sequence is repetition of tones at a higher level (Prier 1996: 28).

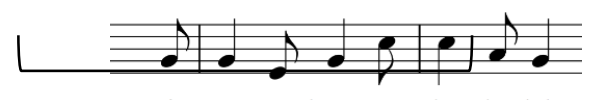

Pin - tu ger-bang ter - bu - ka-lah

$1^{\text {st }}$ motive of A sentence become

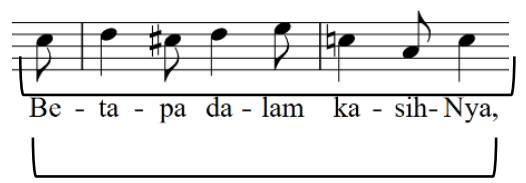


$1^{\text {st }}$

motive of B sentence

$5^{\text {th }}$ Notation: each $1^{\text {st }}$ motive in A and B sentence on Pintu Gerbang Terbukalah song, Alberta, personal documentation. (made on July $4^{\text {th }}$, 2019)

Then the sequence drops off again found in 2nd motive of $B$ sentence $b$. Sequence that drop down is generally in the reply because it gives the impression of 'loosening tension', but it does not mean that it cannot be found in the question sentence as it was in Pintu Gerbang Terbuka song.

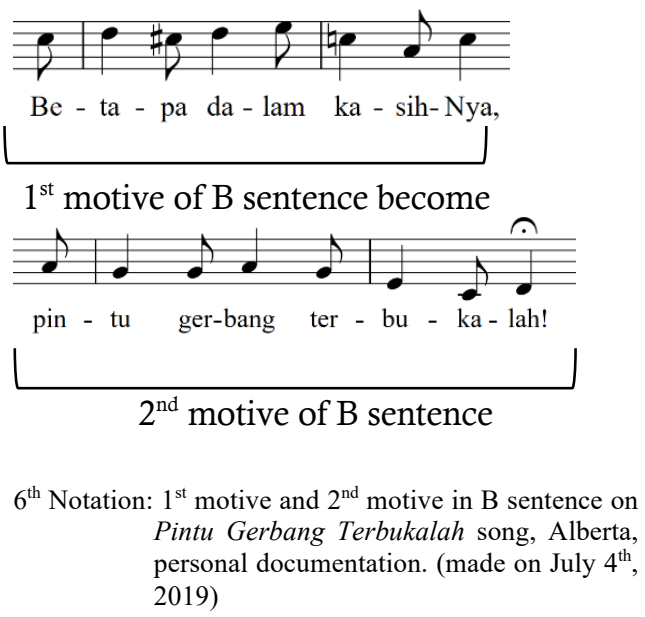

In consequent phrase of $b$ sentence, there was a processing of a kind of augmentation of value in $4^{\text {th }}$ motive. Enlargement of the value of this tone is a doubling of the value of the tone (Prier, 1996: 33).

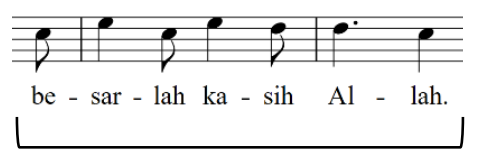

$4^{\text {th }}$ motive of A sentence become

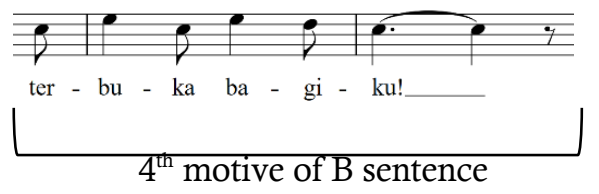

$7^{\text {th }}$ Notation: each $4^{\text {th }}$ motive in A and B sentence on Pintu Gerbang Terbukalah song, Alberta, personal documentation. (made on July $4^{\text {th }}$, 2019)

Next, the subject of the cadence used in the song "Pintu Gerbang Terbukalah". Each of the antecedent phrases in A sentences and B sentences ends with a chord $\mathrm{i}-\mathrm{v}$ so that $\mathrm{A}$ and $\mathrm{B}$ antecedent phrase used an authentic half(half) cadence. Sinaga (2016: 62) explains the half-authentic cadens are I-V chord movements where the chord movement as a marker of a question phrase has a floating / unfinished impression. Whereas the consequent phrases both sentence A and sentence $B$ end with the movement of the dominant chord to the tonic (V-I). This chord movement uses authentic kadens. Sinaga (2016: 62) explains that an authentic imperfect Kadens is a move of the V-I chord. With the cessation of the end of the consequent phrase to the tonika chord, it further affirms that the consequent phrase from the "Pintu Gerbang Terbukalah" suggests that the song is finished. This is reinforced by Prier's theory (1996: 2) which explains that the consequent phrase is called 'answer' or 'back sentence' because it continues 'question' and stops with 'point' or Tonika chord.

\section{"Jalan Hidup Tak Selalu" Song Analysis}

The song "Jalan Hidup Tak Selalu" was an I.H. Meredith song and the poem written by Flora Kirkland (under the original title Love's Rainbow, translated by E.L. Pohan). This song is composed of 24 barline and is incorporated into the form of $\mathrm{A} \mathrm{A}^{\prime} \mathrm{B}=\mathrm{A}\left(\mathrm{a} \mathrm{a}^{\prime}\right), \mathrm{A}^{\prime}(\mathrm{a} \mathrm{x}), \mathrm{B}(\mathrm{b} \mathrm{y})$. Various types of motif processing are included in the song. But as with the opening of the gateway song, motive 1 in the song of the way of life is not always the basis for the development of subsequent motives. The sentence sequence A A 'B is the song sentence $A$ is repeated with variations (hence the code $A^{\prime}$ ), then just enter the sentence B (Prier, 1996: 2)

Various types of motif processing are included in the song. But as the opening of Pintu Gerbang Terbuka song, 
$1^{\text {st }}$ motive in the song of Jalan Hidup Tak Selalu become the basic for the development of subsequent motives.

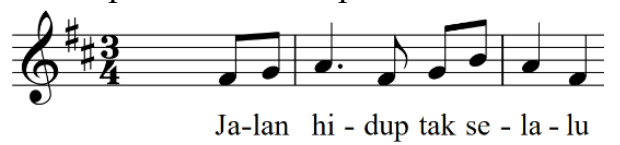

$8^{\text {th }}$ Notation : $1^{\text {st }}$ motive in A sentence on Jalan Hidup Tak Selalu song, Alberta, personal documentation. (made on July $4^{\text {th }}, 2019$ )

Following the processing of the motif found in the song of the way of life is not always: in consequent phrase of $\mathrm{A}$ senctence, the sequence rises is found in $3^{\text {rd }}$ motive which is a repetition of $2^{\text {nd }}$ motive A sentences. An ascending sequence is a repetition of notes at a higher level (Prier, 1996: 28).

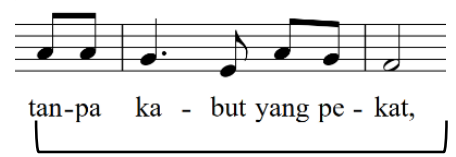

$2^{\text {nd }}$ motive of A sentence become

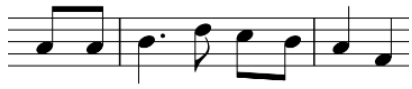

na-mun ka - sih Tu-han nya-ta

na-mun ka - sih Tu-han nya-ta

$3^{\text {rd }}$ motive of A sentence

$9^{\text {th }}$ Notation $: 2^{\text {nd }}$ motive and $3^{\text {rd }}$ motive in A sentence on Jalan Hidup Tak Selalu song, Alberta, personal documentation. (made on July $4^{\text {th }}$, 2019)

Next up is a augmentation treatment ambitus found in $1^{\text {st }}$ motive of antecedent phrase in A sentence. Prier (1996: 29) explains that the enlargement of an interval: a motif consists of several tones, and thus also formed several consecutive intervals. One interval can be enlarged in time repeated.

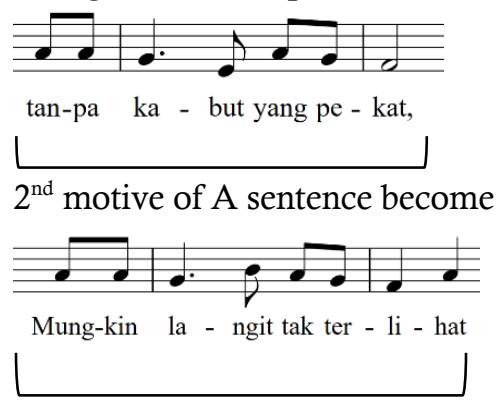

\section{$1^{\text {st }}$ motive of $\mathrm{A}^{\prime}$ sentence}

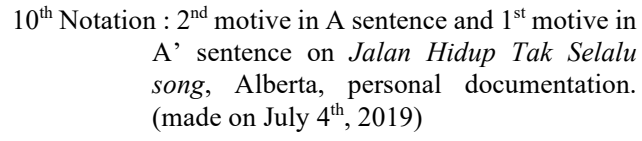
A' sentence on Jalan Hidup Tak Selalu song, Alberta, personal documentation. (made on July $4^{\text {th }}, 2019$ )

While augmentation of value was found in $2^{\text {nd }}$ motive in A sentence. Augmentation of the value is a melodic processing; now the rhythm of the motif is changed: each note value is doubled, while the tempo is accelerated (Prier 1996: 33).

The purpose of this type of motif processing of the tone is to create an increase in tension, so that a general enlargement of the tone is found in the question sentence.

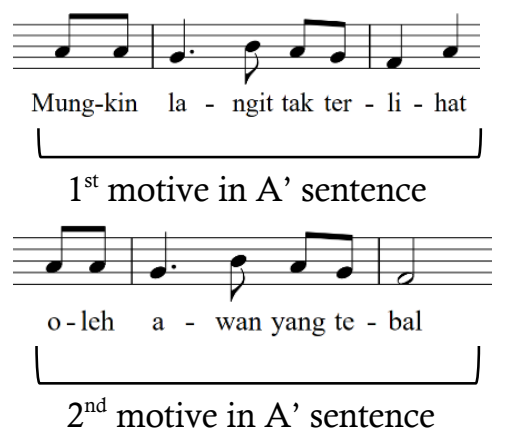

$11^{\text {th }}$ Notation : $1^{\text {st }}$ Motive and $2^{\text {nd }}$ motive in A' sentence on Jalan Hidup Tak Selalu song, Alberta, personal documentation. (made on July $4^{\text {th }}$, 2019)

The processing of motive on the type of sequenced sequence reappears in the 3rdmotive of consequent phrases of $\mathrm{A}^{\prime}$ sentence. Repetition at a higher level is a rerepetition of 1stmotive in A sentence on Jalan Hidup Tak Selalu song.
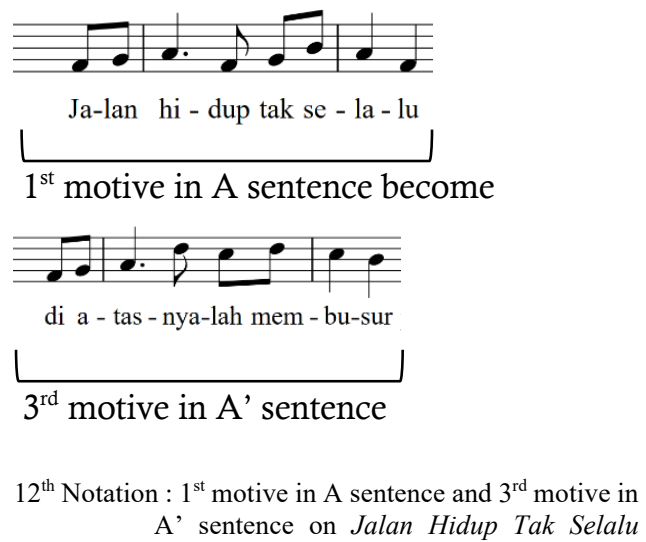
song, Alberta, personal documentation. (made on July $4^{\text {th }}, 2019$ )

Sequence ascent is also found in antecedent phrase in B sentence. Both in $1^{\text {st }}$ and $2^{\text {nd }}$ motive.

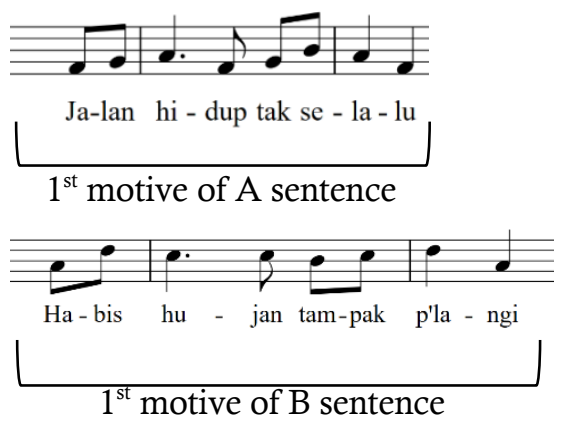

$13^{\text {th }}$ Notation : $1^{\text {st }}$ motive in A sentence and $1^{\text {st }}$ motive in B sentence on Jalan Hidup Tak Selalu song, Alberta, personal documentation. (made on July $4^{\text {th }}, 2019$ )

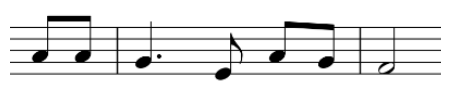

tan-pa ka - but yang pe - kat,

$2^{\text {nd }}$ motive of A sentence

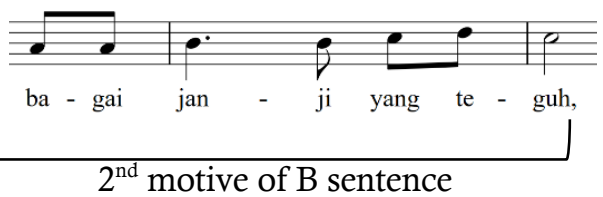

$14^{\text {th }}$ Notation : $2^{\text {nd }}$ Motive in A sentence and $2^{\text {nd }}$ motive of B sentence on Jalan Hidup Tak Selalu song, Alberta, personal documentation. (made on July $4^{\text {th }}, 2019$ )

The processing of a motif like the literal repetition of the $4^{\text {th }}$ motive in $B$ sentence which is the repetition of the $4^{\text {th }}$ motive in A sentence. The purpose of a literary test is to intensify an impression. Or the test intends to confirm a message (Prier 1996: 27).

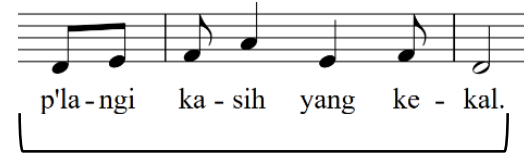

$4^{\text {th }}$ motive in A' sentence become

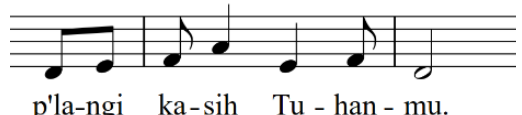

p'la-ngi ka-sih Tu-han-mu.

$4^{\text {th }}$ motive of B sentence

$15^{\text {th }}$ Notation : Each $4^{\text {th }}$ motive in A' and B sentence on Jalan Hidup Tak Selalu song, Alberta, personal documentation (made on July $4^{\text {th }}$, 2019.

The end of each antecedent phrase the song "Jalan Hidup Tak Selalu" ends with a plagiaral kadens for using the IV-V sequence. Sinaga (2016: 63) explains plagal cadens are cadens consisting of chord movements I (tonica) and IV (subdominant). Perfect Plagal cadens are types of Plagal cadens are used because IV-I chord movements. Whereas each consistent phrase or answer sentence ends with an authentic cadence because the dominant chord series - ronica (V-I) ends the question sentence. An imperfect authentic cadens is the movement of the V-I chord (Sinaga, 2016: 62).

\section{"Makin Dekat Tuhan" Song Analysis}

The last song titled "Makin Dekat Tuhan" was Lowell mason's song with a poem written by Sarah f. Adams 1841 based on genesis 28 (under the original title "Nearer, My God, To Thee", translated by the Pohan SHN 1972). This song is composed of 16 barline. This song is a song with a two-part form with the pattern $\mathrm{AB}=\mathrm{A}\left(\mathrm{a} \mathrm{a}^{\prime}\right) \mathrm{B}\left(\mathrm{b} \mathrm{a}^{\prime}\right)$ means the question sentence $A$ is also used as an answer to sentence A or sentence B, but with little variation (Prier, 1996: 9)

Some kind of motif processing can be found in the song "Makin Dekat Tuhan". But $1^{\text {st }}$ motive remains the underlying motive of the song.

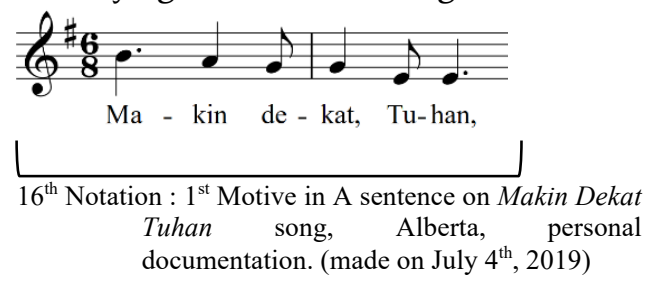


The processing of the kind of motif of a literal repetition found in $3^{\text {rd }}$ motive of A sentence.

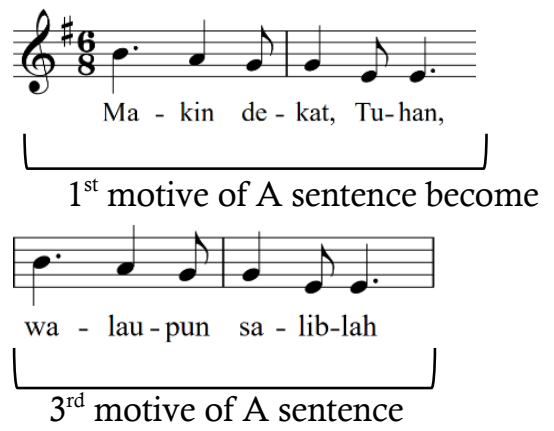

$17^{\text {th }}$ Notation : $1^{\text {st }}$ Motive in A sentence and $3^{\text {rd }}$ motive in A sentence on Makin Dekat Tuhan song, Alberta, personal documentation. (made on July $4^{\text {th }}, 2019$ )

The processing of the descending $4^{\text {th }}$ motif of A sentences. A descending sequence is a motif that is repeated at a lower pitch (Prier, 1996: 28).

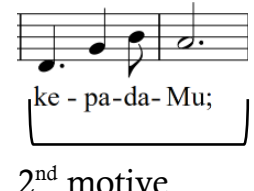

become

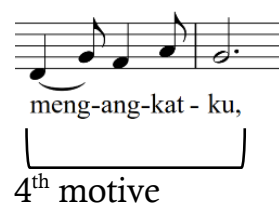

$18^{\text {th }}$ Notation $: 2^{\text {nd }}$ motive and $4^{\text {th }}$ motive in A sentence on Makin Dekat Tuhan song, Alberta, personal documentation. (made on July $4^{\text {th }}$, 2019)

And then on $2^{\text {nd }}$ motive in B sentence, the processing of the motif type of diminuation of the ambitus is found. If the enlargement of the interval (augmentation of the ambitus) is the enlargement of the interval when repeated, then the reduction of the interval is the opposite, namely the reduction of the interval when experiencing repetition (Prier 1996: 30).

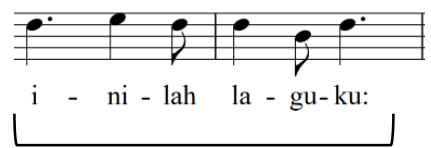

$1^{\text {st }}$ motive of $B$ sentence become

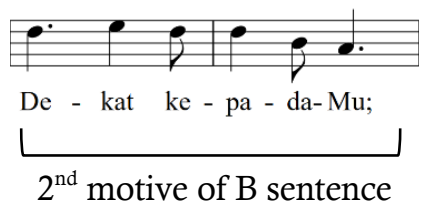

$19^{\text {th }}$ Notation : $1^{\text {st }}$ motive and $3^{\text {rd }}$ motive in B sentence on Makin Dekat Tuhan song, Alberta, personal documentation. (made on July $4^{\text {th }}, 2019$ )

In this song, answer phrases of $B$ sentence is a recurrence of phrase of $\mathrm{A}$ sentence so that the processing of a motif of a type of literal repetition is also found in $3^{\text {rd }}$ and $4^{\text {th }}$ motive in B sentences.
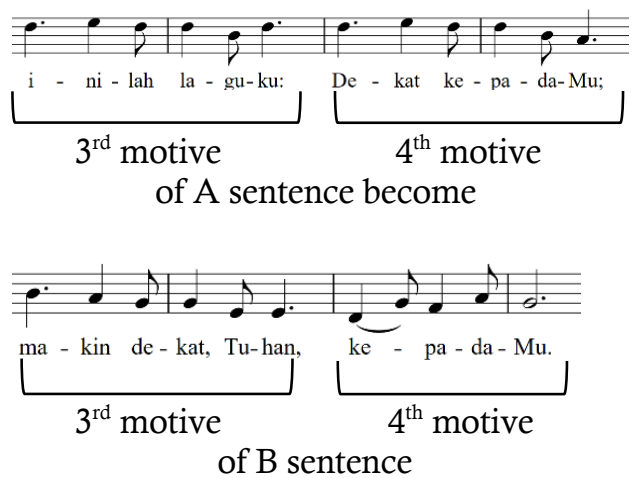

$20^{\text {th }}$ Notation : Each $3^{\text {rd }}$ and $4^{\text {th }}$ motive in A and B sentence on Makin Dekat Tuhan song, Alberta, personal documentation. (made on July $4^{\text {th }}, 2019$ )

Next is the discussion of the cadence used in the song "Makin Dekat Tuhan". The akor I-V movement is used at the end of the question sentence so that a portion of the cadence reappears in the question sentences of the song. This is because the half-authentic cadens are I-V chord movements where the chord movement is a marker of a question phrase, has a floating / unfinished impression (Sinaga 2016: 62). Whereas the movement of akor V-I was used in both A sentence and B sentences for an authentic cadence to end the answer sentence in "Makin Dekat Tuhan" Incomplete authentic cadence is the movement of cord V-I ends in cord I (Sinaga, 2016: 62). 


\section{"Tuhan Allah Beserta Engkau" Song Analysis}

The last song to be analysed is the song titled "Tuhan Allah Beserta Engkau". It is a song by William g. tomer in 1883 and a verse written by a different man named Jeremiah rankin in 1880 (under the original title God Be With You, translated by yamuger 1978). This song consists of 16 bars and is a two-part song with the pattern $A B=A\left(a a^{\prime}\right) B\left(b b^{\prime}\right)$, which means that two questions are repeated varying in answers (Prier 1996: 9).

Some motif processing can also be found in the song "Tuhan Allah Beserta Engkau". But the motive of the song remains the overall basis of the motive in the song.

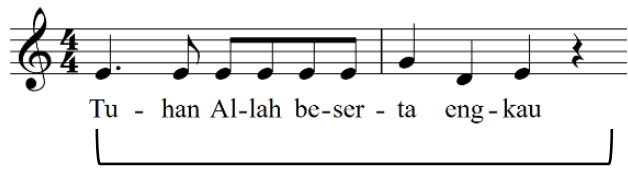

$21^{\text {th }}$ Notation : $1^{\text {st }}$ motive in A sentence on Tuhan Allah Beserta Engkaun song, Alberta, personal documentation. (made on July $4^{\text {th }}, 2019$ )

On the $2^{\text {nd }}$ motive of phrase anteseden in A sentence, is found the processing of the type of motif of the sequens goes up. An ascending sequence is a motif that is repeated at a higher pitch level (Prier, 1996: 28).

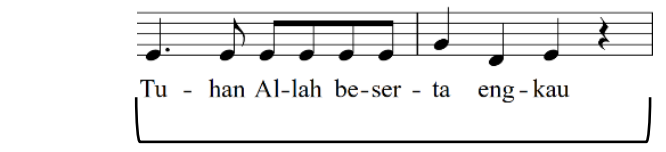

$1^{\text {st }}$ motive of A sentence become

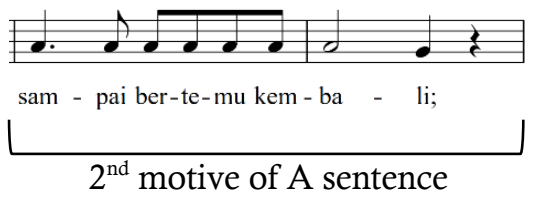

$22^{\text {th }}$ Notation : $1^{\text {st }}$ motive and $2^{\text {nd }}$ motive in A sentence on Tuhan Allah Beserta Engkaun song, Alberta, personal documentation. (made on July $4^{\text {th }}, 2019$ )

Further, the processing of the underlying motif of the down sequence can be found in $3^{\text {rd }}$ motive of A sentence. Prier (1996: 28) Down sequence: a motif can also be repeated at a lower pitch.

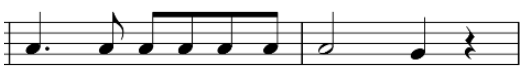

sam - pai ber-te-mu kem - ba - li;

$2^{\text {nd }}$ motive of A sentence become

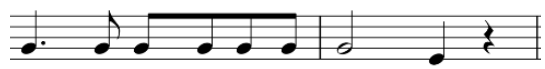

ka - sih Kris-tus me-nga-wal - i,

$3^{\text {rd }}$ motive of A sentence

$23^{\text {th }}$ Notation : $2^{\text {nd }}$ motive and $3^{\text {rd }}$ motive in A sentence on Tuhan Allah Beserta Engkaun song, Alberta, personal documentation. (made on July $4^{\text {th }}, 2019$ )

In the next phrase, which is antecedent $B$ sentence, $2^{\text {nd }}$ motive used the rise sequence again as the processing of the motive.

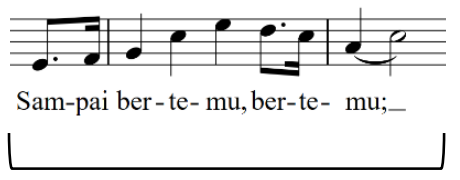

$1^{\text {st }}$ motive of B sentence become

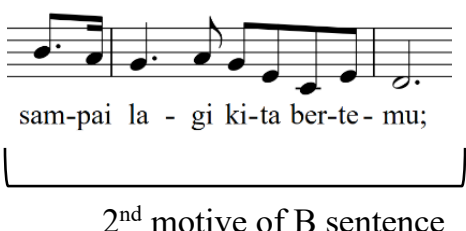

$24^{\text {th }}$ Notation : $1^{\text {st }}$ motive and $2^{\text {nd }}$ motive in A sentence on Tuhan Allah Beserta Engkaun song, Alberta, personal documentation. (made on July $4^{\text {th }}, 2019$ )

Finally, the processing of literal repetition type of motif found in $3^{\text {rd }}$ motive of $B$ sentence. $3^{\text {rd }}$ motive is repetition of $1^{\text {st }}$ motive on antecedence phrase of $B$ sentence.

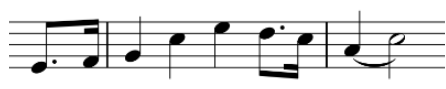

Sam-pai ber-te- mu, ber-te- mu;

$1^{\text {st }}$ motive of $\mathrm{B}$ sentence become 


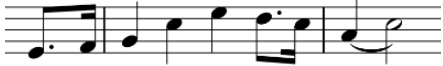

Sam-pai ber-te- mu, ber-te- $\mathrm{mu}$;

$3^{\text {rd }}$ motive of $B$ sentence

$25^{\text {th }}$ motive : $1^{\text {st }}$ motive and $3^{\text {rd }}$ motive in A sentence on Tuhan Allah Beserta Engkaun song, Alberta, personal documentation. (made on July $4^{\text {th }}$, 2019)

The use of cadence in the song "Tuhan Allah Beserta Engkau" is slightly different from the other sample of the song. The movement of IV-I chord is found in a consequent phrase or a sentence of answer though this is likely to occur in other songs. The plagiaral cadence is an IV-I movement (Sinaga, 2016:62). The plagiaral cadence is also found in question sentences that is A sentence and in B sentences, in the phrase the question use a half kadens because it use the I-V chord movement, and the answer phrase in the $B$ sentence use the authentic cadence and the chord movement used is the V-I.

\section{Explaination}

Based on the above study of a song form analysis found in Kidung Penghiburan, which is entitled "Pintu Gebang Terbukalah" (Kidung Penghiburan no.1), "Jalan Hidup Tak Selalu" (Kidung Penghiburan no. 14), "Makin Dekat Tuhan" (Kidung Penghiburan no.22), dan "Tuhan Allah Beserta Engkau" (Kidung Penghiburan no.46), is a two-part song (song part a and part b). Possible sequences on each song are different from each other. Nevertheless, each sentence remains two phrases of antecedent phrase and a consequent phrase. This harmonizes with the theory presented by Prier (1996:2) that describes the musical sentence as either sentence or phrase, which is a front or a question sentence (antecedent phrase) and the back or answer phrase (consequent phrase). The study is similar to the previous study, where the associated study is the song form analysis in the song of the form and function of the hymns in the Sunday Worship at GKI Gajahmada (Wijoyo, 2014). The song "Allah Roh Kudus" is a two-part song. Similar studies have shown different results. (Wijoyo, 2014) in music analysis praises for Sunday worship at GBI Gajahmada explains that the song " $K u d i$ Beri Kuasa" is a three-part song. As for another similar study by the Saputra (2016) who described the song "Jangan Aku Dilalui as a two-part pattern A (a a '), B (b a ') while the song "Berkati Persembahanku" and "Bapa Antarlah Kami" were one-part song A (a a '). This difference is caused by the different set of song books used for worship.

\section{CONCLUSION}

Based on the study entitled "The Form And Structure Of Selected Songs From Kidung Penghiburan For The Consolation Worship In GKI Indramayu", it could be concluded that a song form titled Pintu Gerbang Terbukalah, Jalan Hidup Tak Selalu, Makin Dekat Tuhan, dan Tuhan Allah Beserta Engkau. As for the structure of each song being: 1) "Pintu Gerbang Terbukalah" song, is two-part song. This song consists of A sentence with (a a') pattern and B sentence with (b y) pattern. 2) "Jalan Hidup tak Selalu" song is two-part song. The A sentence has (a a') pattern, A' sentence with ( $\mathrm{a} x)$ pattern, and B sentence with (b y) pattern. 3) "Makin Dekat, Tuhan" song is two-part song with A sentence that has $A(a$ a') pattern and $B$ sentence with (b a') pattern. 4) "Tuhan Allah Beserta Engkau" song is two part song with A sentence that has (a a') pattern and $B$ sentence with ( $b$ a') pattern.

\section{REFERENCES}

Adimurti, J. T. (2005). Inkulturasi Musik Gereja di Batak Toba dan Simalungun. Harmonia: Journal of Arts Research and Education, VI(3).

Destiana, E. (2016). Analisis Bentuk dan Struktur Lagu Stambul Baju Biru Karya Hardiman. Pedagogia ISSN, 5(2), 209-214.

Jamalus. 1988. Pengajaran Musik Melalui Pengalaman Musik. Jakarta. Depdikbud.

Moleong, Lexy J. 2007. Metodologi Penelitian Kualitatif. Bandung. Remaja Rosdakarya. 
Ottman, Robert W. 1961. Elementary Harmony: Theory and Practice. New Jersey: Prentice-Hall, Inc.

Pasila, D. (2017). Badong Sebagai Penghiburan Atas Dukcita Dalam Upacara Rambu Solo' Masyarakat Kristen Lameme. UNIVERSITAS KRISTEN SATYA WACANA SALATIGA.

Prier, KE, Sj. 1996. Ilmu Bentuk Musik. Yogyakarta: PML.

Rachman, A. (2013). Bentuk Dan Analisis Musik Keroncong Tanah Airku Karya Kelly Puspito. Harmonia: Journal of Arts Research and Education, 13(1), 69-77.

Roziqin, M. K., \& Sarjoko, M. (2018). Karya Musik " Overture Ul- Daul " Dalam Tinjauan Variasi Melodi. Jurnal Solah, 8(1), 1-12.

Siahaan, R. (2012). Apa dan Bagaimana? Ciri Nyanyian Jemaat Kategori Nyanyian Jemaat. Jurnal Jaffray, 2(10), 157-165.

Sinaga, Syahrul S. 2016. Harmoni Dasar Teori dan Implikasi dalam Lagu. Cetakan Terbatas.

Suryanto, L. K. D. (2014). Pengaruh Musik Iringan Ibadah Impresif Terhadap Jumlah Jemaat GKI Gejayan Yogyakarta. UNIVERSITAS NEGERI YOGYAKARTA.

Wijoyo, K. (2014). Analisis Bentuk Dan Fungsi Musik Pujian Dan Penyembahan Dalam Ibadah Minggu Di GBI Gajah Mada Semarang. Jurnal Seni Musik, 3(1), 17.

Yusuf, M. (2017). Perubahan, Kontinuitas, Struktur Musik, Dan Teks Realisasi Nyanyian Buku Ende dan Kidung Jemaat Yamuger, 1(1), 40-48. 